\title{
ENTERPRENEURSHIP AND KOPERASI SOCIALIZATION IN BANYU ASIH VILLAGERS FOR INDEPENDENT VILLAGE COMMUNITIES
}

\author{
Verliani Dasmaran, and Hendi Prihanto, Islamiah Kamil, Kurnia Sari Dewi \\ Mathlaul Anwar Universitity, Malaysia. \\ Universitas Prof. Dr. Moestopo (Beragama), Indonesia. \\ verliani.dasmaran@gmail.com
}

\begin{abstract}
Banyu Asih Village is a village located in Cigeulis Sub-district, Pandeglang Regency, which is located on the coastline affected by the Sunda Strait tsunami. As a result of the disaster, efforts to revive the community's economy are a joint task of all parties, people who have an entrepreneurial spirit are expected to be able to rebuild the village economy towards a more independent and developed village. This activity aims to provide understanding to the community related to entrepreneurial activities that support the potential of the village and community awareness in cooperatives to overcome capital and prevent usury and loan sharking behavior in village areas that will not solve the problem, but increase the problem. The results of this activity are expected to be able to provide business communities with understanding and motivation so that the community is able to recognize the business potential in the Banyu Asih village.
\end{abstract}

Keywords: Socialization, Enterpreneurship, Cooperative, Independent Villagers

\section{INTRODUCTION}

Entrepreneurship is a continuous process of doing or creating something new in a creative and innovative way that benefits others and adds value (Achmad, 2015) :(Achmad \& Saputro, 2016). Entrepreneurship comes from the word entrepreneur and business, entrepreneur means hero or warrior, while business means doing something as stated by Robbins \& Coulter (2010). For this reason, entrepreneurship can be defined as a process whereby a person or group of individuals uses organized efforts $\&$ means to find an opportunity and create a value that grows by meeting their needs and desires through an innovation \& uniqueness, regardless of any resources used at the time being.

Suryana (2014) states that success in entrepreneurship is determined by three factors, which include the following: 1) Ability and willingness, because someone who does not have the ability, but many wills and people who have the will, but do not have the ability, both will not be a successful entrepreneur. Conversely, people who have the will equipped with abilities will become successful. Willingness is not enough if it is not equipped with abilities. 2). Strong determination and hard work, someone who does not have a strong determination, but has a desire to work hard and people who like to work hard, but do not have a strong determination, both will not be successful entrepreneurs. 3). Opportunities and opportunities. There is a solution there is an opportunity, otherwise there is no solution there will be no opportunity. Opportunities exist if we create opportunities ourselves, not looking for or waiting for opportunities that come to us.

The aim of this entrepreneurial activity is to increase the number of strong and qualified entrepreneurs, and to give awareness to the community to be entrepreneurs with strategies that support maximum success and to cultivate the spirit of entrepreneurial attitudes, behaviors, and abilities among people who are capable, reliable, and superior. In line with Wahyudin, (2012) the goal of entrepreneurship with community independence in the countryside is very closely by applying the right methods to create a community able to stand up and advance in developing village potentials owned by the village and giving a good contribution in creating progress in the village economy. Factors that shape entrepreneurial behavior are innate, the environment around the community, and the training or education carried out. For this reason, training and education are factors that can most stimulate the entrepreneurial spirit in an individual. Strategy through sharing entrepreneurship educators who are open to enrich and criticized makes it easy to achieve goals. Then supported by educators who must have competence in the field of entrepreneurship training and education and have adequate business entrepreneurial experience.

Banten was part of West Java province after being released from West Java, the development in Banten is proved with the increase of PAD (regional original income) from year to year. One of the Banten formation actors, Embay Mulya Syarief, confirmed the purpose of forming this region was to eliminate disparity with West Java. Thus there is a push so that there is an acceleration of welfare for the region which is closely with the history of the Sultanate of Banten. Based on BPS the development of PAD can be seen in Figure 1. 


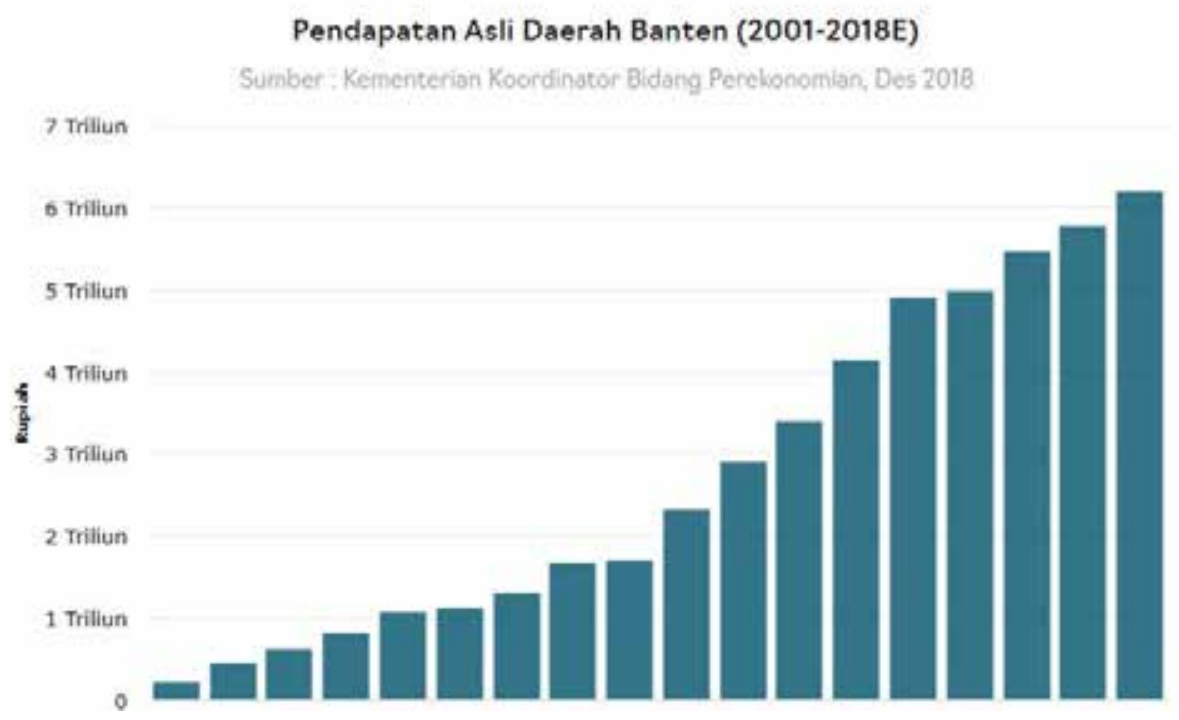

Figure 1. Banten Original Income (2001 - 2018 E)

Source: Coordinating Ministry for Economic Affairs, December 2018

Banyu Asih is a village in Cigeulis sub-district in South Banten region. Problems in Banyu Asih village related to entrepreneurship are accompanied by other problems, namely capital problems and the circulation of funds at the village level. Thus providing cooperative socialization is the best step in overcoming these problems.

Banyu Asih Village is a village that has a coastal area that has natural potential, the potential of marine products that can be used as a source of business for the community. The trauma of the Sunda Strait tsunami has become a problem in re-cultivating marine products. To raise the spirit of entrepreneurship is considered very important considering the rural community needs a sector to generate business sector so that there is no large urbanization to the city. Cooperatives are the right vehicle in realizing the people's economic goals that are strong and resistant to the threat of crisis.

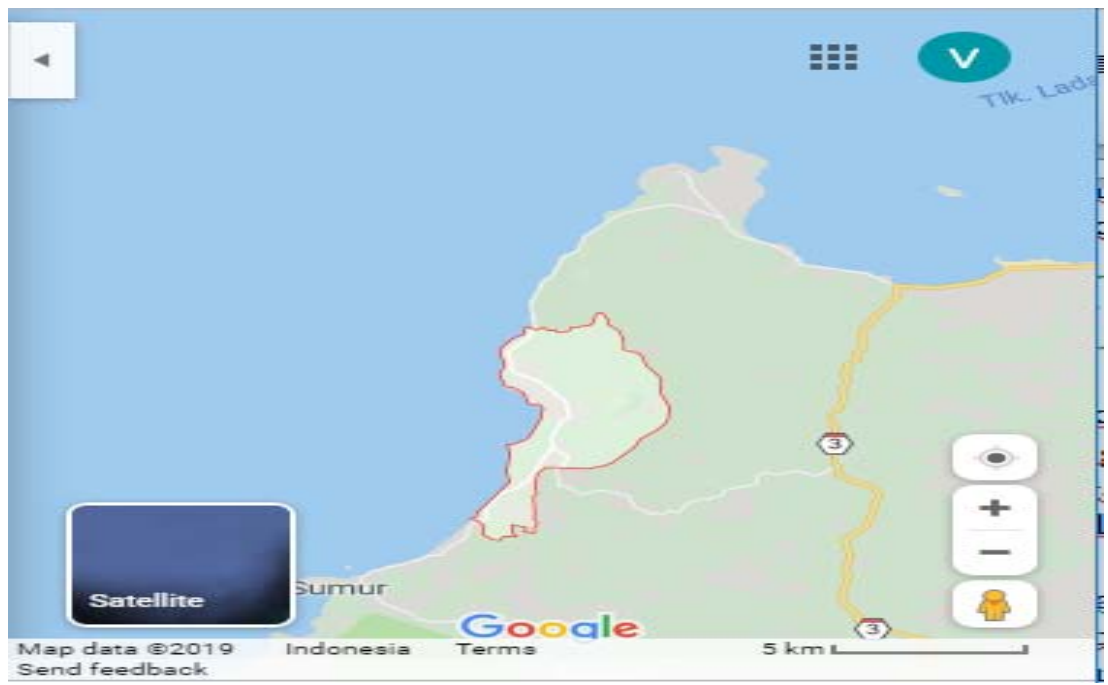

Figure 2. map of Banyu Asih, Cigelis sub-district Pandeglang Banten

Definition of Koperasi according to law no.25 / 1992, is a business entity consisting of people or cooperative legal entities, based on its activities based on cooperative principles as well as a people's economic movement based on the principle of kinship. The main objective of cooperatives in the community is to help improve the welfare of its members. Whereas in the cooperative law is more detailed into several cooperative objectives: 1) to improve the standard of living of members of the cooperative and the surrounding community. and prosperous., 4) Cooperatives play a role in building the national economic order. 
In the community, especially Banyu Asih Village, the function of community cooperatives formed can 1) build and enhance the economic potential of the members where the members are entrepreneurs from various sectors, 2) has an active role in improving the quality of life of members and also the community can avoid usury and bonded labor, 3) strengthen and develop a better national economy through joint and profitable efforts together with the principle of mutual cooperation.

The form of cooperatives in Indonesia can be seen based on 1). According to its function, 2). According to the level and extent of work and 3). According to the field of business. While cooperatives in Indonesia can be divided into two namely Primary Cooperatives and Secondary Cooperatives. Based on this type of cooperative that is suitable to be established in the village of Banyu Asih based on its function is a consumption cooperative, which is a cooperative whose activities are as a sole distributor of goods for members' daily needs or shortening the distance (distribution) between producers and consumers, and its members come from people who have a direct interest in the consumption field. Besides functioning as a sole distributor of goods for basic needs of members, other functions of consumer cooperatives are: 1) can meet daily needs easily, 2) the quality of goods is more guaranteed, 3) the price is cheaper or equal to the market price, 4) the remainder of the business results obtained are returned to the members, 5) the costs of selling or purchasing costs can be saved. This is because the distance from district of Pandeglang is more than $100 \mathrm{Km}$.

Based on the level and extent of cooperatives that are suitable in Banyu Asih village are primary cooperatives, it's a cooperative established by at least 20 people who subsequently become members of the cooperative itself. So the working area includes one work environment, it can also be from one village or one village. Based on the field of business and analysis developed from the PKM Team (Universitas Matlaul Anwar Banten and the University of Prof.Dr.Moestopo (Religious) Jakarta, the suitable cooperatives in Banyu Asih are multi-purpose cooperatives, namely cooperatives that have multiple fields or many businesses. Village Unit Cooperatives (KUD) and multi-business cooperatives.

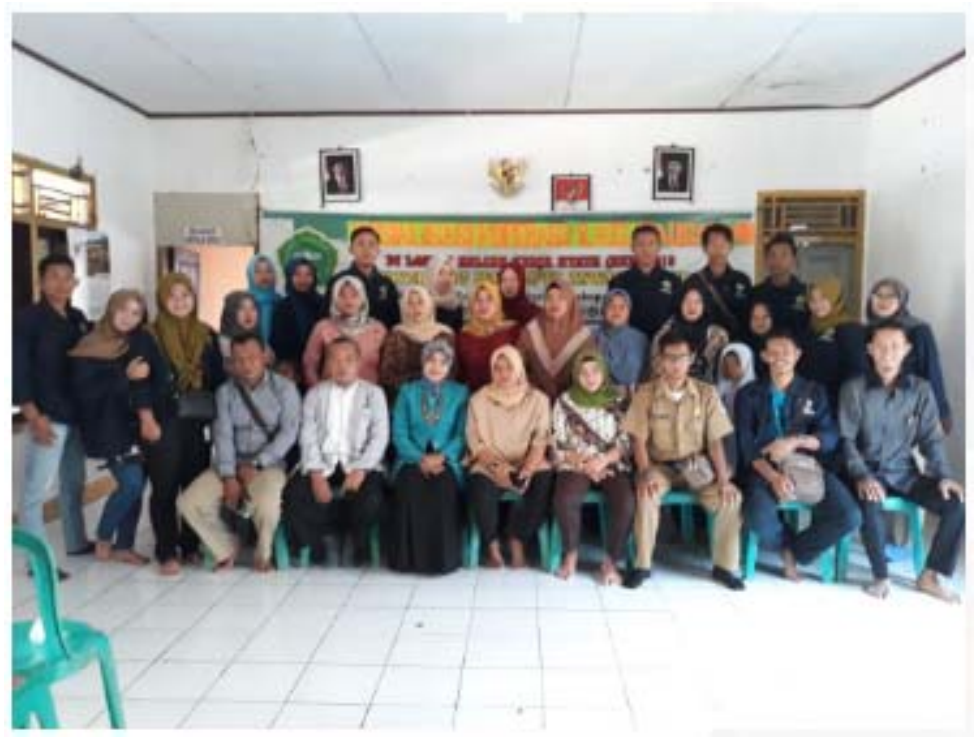

Figure 3. Communities participation

\section{IMPLEMENTATITON METHOD}

The target in the activity is the Banyu Asih village community who is the representative of each RT and RW as well as the BUMDes management and community leaders who are able to move the community and are able to forward information to other communities, so that entrepreneurial material and cooperative socialization material can be conveyed back to other communities. Participants were 30 representatives from 8 RWs and 25 RTs.

The method of delivering information is done through socialization using face-to-face communication (lectures) and questions and answers, and added examples of businesses that are potential in the area. Then do an analysis of how business processes involving income prospects and the production and marketing processes of these products. In entrepreneurship and cooperative socialization activities, tools such as infocus, laptops, paper, materials etc. that have been adapted to the material are used.

This entrepreneurship socialization activity took place on Monday 5 August 2019 at the office of the Banyu Asih village head, in addition to the PKM team this activity was attended by village officials, BUMDes representatives and the local community from $25 \mathrm{RT}$ scattered in the area. 


\section{RESULT DISCUSSION}

In this socialization activity is a collaboration between universities namely the Faculty of Economics and Business Mathlaul Anwar University Banten and the Faculty of Economics and Business University Prof. Dr. Moestopo (Religious) as the core team, as well as with XX groups of KKN Students from Mathlaul Anwar University and supported by all Banyu Asih Village officials.

One week before the activity, the team conducted a survey assisted by KKN students to dig up information related to business sectors in Banyu Asih Village, the potentials in Banyu Asih Village, the economic condition of the community, culture and other things that can be used as references in convey appropriate entrepreneurial activities and support with the objectives of the activity.

At the time of service PKM participants were asked to mention what businesses they wanted to start, those who had or who did not have a business, then a group discussion session was made on how the stages of the business they wanted to start and the desired process and outcome, so the Team knew the extent where people know the business world and the business potential that exists around their environment.

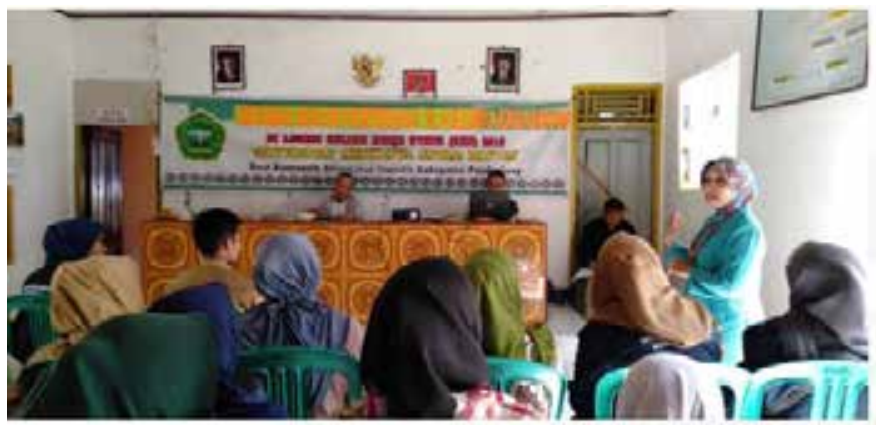

Figure 4: dialogue activity during the enterpreneurship and koperasi socialization

From the results of the data collection using the direct survey method, the most potential participants in the business of processing sea fish into fish meatballs, processing palm sugar, making salting fish, selling rice and garden products such as rice, watermelon, melinjo, jengkol, coconut, etc. While the problems that occur from some of the potentials contained in the Banyu Asih village are: 1) simple processing so that the product does not last long; 2) lack of variations in the products produced must still be equipped with knowledge of food preparations; 3) less attractive product packaging; 4) marketing that is not extensive; 5) knowledge of how durable the product is; 6) lack of calculation in determining the cost of production; 7) minimal capital; 8) not yet formed a business group or joint venture of similar products; 9) many people are in debt with traveling banks in meeting their capital sources; 10) lack of business motivation in developing regions due to the orientation of the community to work abroad or outside the non-formal sector. The enthusiasm of the residents who took part in the PKM activities was shown in the following figure 5, which was very attentive and focused following the counseling, and heeded the direction of the PKM team.

Another interesting thing is the activities that have been carried out and the question and answer session can be seen the enthusiasm (curiosity) of the community in participating in entrepreneurship socialization activities but it is hoped that Banyu Asih villagers will receive assistance in carrying out marketing activities. PKM is a production strategy and how to get capital by involving investors, but not from interest-bearing loans. Especially in the formation of cooperatives that can benefit society. Then no less important is the recording system to the accountability of members or the community.

The condition of the community which is $95 \%$ are farmers and fishermen, it is necessary to classify by type of business so that if there is further training it is more directed and targeted, but in the formation of cooperatives it can be combined so that more members and facilitation is easier, or cooperatives with multi-purpose. But in the implementation, it is needed a proper assistance and supervision so that it can run as expected.

The biggest reason for cooperatives can be used as a solution in Banyu Asih is that there are already many high-interest bank prectics such as mobile banks that can threaten the community with usury techniques and harm the community and avoid bonded practices from unscrupulous middlemen and cause problems financially in the future. In accordance with the above theory, the practice of cooperatives is an important factor in supporting the economy of the community in the Banyu Asih area.

\section{CONCLUSSION}

From the above Entrepreneurship and Cooperative Socialization activities, the team concluded several things as follows (1) Community knowledge about entrepreneurship and cooperatives is still very minimal and limited. There are still assumptions that can carry out business activities are people who have experience and have large 
capital, (2) PKM participants have an enthusiasm in entrepreneurship and cooperative socialization activities because they open up insights so much the potential business potential that exists around their homes. (3) Based on research references and direct observation on the media and direct data sources, the independence of the village community is very important in driving the regional economy and increasing local original income so that several parties can be involved in implementing and handling seriously in shaping the character and metal of entrepreneurship in the community. (4) Assistance in providing capital is the most real step that must be done by involving banks and third parties, but the community is equipped with accountability and transparency capability that can foster trust (5) Continuity of activities towards the same target so that progress in society can be monitored and realized.

\section{ACKNOWLEDGEMENT}

Community Service Team Faculty of Economics and Business Mathlaul Anwar University Banten and Prof. University Dr. Moestopo (Religious), expressed the highest appreciation to all those who have provided assistance for this activity, namely: (1) Chancellor of Mathlaul Anwar University Banten (2) Chancellor of the University of Prof. Dr. Moestopo (Religious), (3) Research and Community Service Institute, Banten Anwar University Banten, (4) Research and Community Service Institute, Prof. University Dr. Moestopo (Religious), (5) Dean of the Faculty of Economics and Business Mathlaul Anwar University Banten (6) Dean of the Faculty of Economics and Business UPDM (B) Jakarta, (7) Head of Banyu Asih Village, Cigeulis District, Pandeglang Regency, Banten and their staff (8) Groups XX 2019 KKN Mathlaul Anwar University Banten.

\section{REFERENCE}

Achmad, N. (2015). Kewirausahaan: Suatu Alternati Menuju Kesuksesan. (B. F. UMS, Ed.). Surakarta. Achmad, N., \& Saputro, E. P. (2016). kewirausahaan Di Era Digital. Jakarta: Direktorat Penelitian pengabdian Masyarakat Dirjen Dikti.

Baswir, Revrisond. 2000. Koperasi Indonesia. Yogyakarta: BPFE-Yogyakarta.Kasali, Rhenald dkk. 2012. Kewirausahaan. Hikmah : Jakarta.

Badan Perencanaan Pembangunan Nasional. 2008. Pemberdayaan Koperasi, Usaha Mikro, Kecil, dan Menengah. http://www.bappenas.go.id. (2 Januari 2016

Helmi, Faisal, Zaini, A. 2014. Pembangunan Pedesaan. Artikel

Kumorohadi, Untung \& Nurhayati. 2010. “Analisis Kualitas Pembinaan dan Pengembangan Jiwa Kewirausahaan di Kalangan Mahasiswa". Unsud : Purwokerto.

Meredith, G. Geoffrey et al. 1996. Kewirausahaan Teori dan Praktek. PT Pustaka Binaman Pressindo : Jakarta.

Pandeglang dalam Angka 2019

Robbins, S. P., \& Coulter, M. (2010). manajemen (10 th). Jakarta: Erlangga.

Sitio, Arifin dan Halomoan Tamba. 2001. Koperasi Teori dan Praktek. Jakarta: Erlangga.

Undang-undang no.20 tahun 2008 tanggal 4 Juli 2008 tentang Usaha Mikro, Kecil dan Menengah.

UU No. 25 / 1992 tentang Koperasi

Wahyudin, U. Y. U. (2012). Pelatihan Kewirausahaan Berlatar Ekokultural untuk, XXVIII(1), 55-64. 